\title{
Collagenase-2 (matrix metalloproteinase-8) plays a protective role in tongue cancer
}

\author{
JT Korpi', V Kervinen², H Mäklin², A Väänänen², M Lahtinen ${ }^{3}$, E Läärä ${ }^{3}$, A Ristimäki ${ }^{4}$, G Thomas $^{5}$,

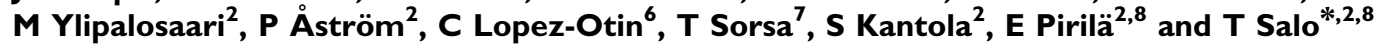 \\ 'Department of Oral and Maxillofacial Surgery, Institute of Dentistry, University of Oulu and Oulu University Hospital, Oulu, Finland; ${ }^{2}$ Department of \\ Diagnostics and Oral Medicine, Institute of Dentistry, University of Oulu and Oulu University Hospital, Oulu, Finland; ${ }^{3}$ Division of Statistics, Department of \\ Mathematical Sciences, University of Oulu, Oulu, Finland; ${ }^{4}$ Department of Pathology, University of Helsinki, Helsinki, Finland; ${ }^{5}$ Tumor Biology Laboratory, \\ Cancer Research UK Clinical Centre, Barts and the London School of Medicine and Dentistry, London, UK; ${ }^{6}$ Departamento de Bioquimica y Biologia \\ Molecular, Instituto Universitario de Oncologia, Universidad de Oviedo, Oviedo, Spain; ${ }^{7}$ Department of Oral and Maxillofacial Diseases, Institute of \\ Dentistry, University of Helsinki and Helsinki University Central Hospital, Helsinki, Finland
}

Squamous cell carcinoma (SCC) of the tongue is the most common cancer in the oral cavity and has a high mortality rate. A total of 90 mobile tongue SCC samples were analysed for Bryne's malignancy scores, microvascular density, and thickness of the SCC sections. In addition, the staining pattern of cyclooxygenase-2, $\alpha v \beta 6$ integrin, the laminin-5 $\gamma 2$-chain, and matrix metalloproteinases (MMPs) -2, -7, -8, -9, -20, and -28 were analysed. The expression of MMP-8 (collagenase-2) was positively associated with improved survival of the patients and the tendency was particularly prominent in females. No sufficient evidence for a correlation with the clinical outcome was found for any other immunohistological marker. To test the protective role of MMP- 8 in tongue carcinogenesis, MMP-8 knockout mice were used. MMP-8 deficient female mice developed tongue SCCs at a significantly higher incidence than wildtype mice exposed to carcinogen 4-Nitroquinoline-N-oxide. Consistently, oestrogen-induced MMP-8 expression in cultured HSC-3 tongue carcinoma cells, and MMP-8 cleaved oestrogen receptor (ER) $\alpha$ and $\beta$. According to these data, we propose that, contrary to the role of most proteases produced by human carcinomas, MMP-8 has a protective, probably oestrogen-related role in the growth of mobile tongue SCCs.

British Journal of Cancer (2008) 98, 766-775. doi:I0.1038/sj.bjc.6604239 www.bjcancer.com

Published online 5 February 2008

(c) 2008 Cancer Research UK

Keywords: squamous cell carcinoma; tongue; MMP-8; matrix metalloproteinases; oestrogen receptor; oestrogen

Squamous cell carcinoma (SCC) of the tongue is the most common type of cancer in the oral cavity and its incidence has increased over the past decades worldwide (Swango, 1996; Alho et al, 1999). SCCs of the tongue behave aggressively and almost half of the patients still die of the disease (Dickman et al, 1999). Efficient intervention of tongue SCCs requires the identification of the most aggressively behaving tumours. Over the past few years, a series of studies have tried to define immunoreactive molecular markers with ability to predict disease recurrence and prognosis of oral SCC patients (Bettendorf et al, 2004; Brinkman and Wong, 2006). In this work, we have addressed this question by analysing at both clinical and molecular levels, a series of tongue cancer cases. This population-based study covered all the patients in Northern Finland with surgically treated SCC in the mobile tongue between the years 1981-2001. Resection samples from 90 eligible mobile

*Correspondence: Dr T Salo, Department of Diagnostics and Oral Medicine, Institute of Dentistry, University of Oulu and Oulu University Hospital, PO Box 528I, Oulu 900 I4, Finland;

E-mail: tuula.salo@oulu.fi

${ }^{8}$ Equal supervisors.

Revised 21 December 2007; accepted 9 January 2008; published online 5 February 2008 tongue SCC patients ( 47 males, 43 females) were analysed using a set of possible new and previously proposed immunohistochemical prognostic markers including microvessel density (CD31 and factor VIII), cyclooxygenase-2 (COX-2), the laminin-5 $\gamma 2$-chain, integrin $\alpha \mathrm{v} \beta 6$ and matrix metalloproteinases (MMP-2, -7, -8, -9, -20 , and -28). The high expression levels of COX-2 are known to be associated with poor disease-free survival in oral squamous cell carcinoma (Pannone et al, 2007) and also laminin-5 $\gamma 2$-chain, a basement membrane protein (Gasparoni et al, 2007), and $\alpha \mathrm{v} \beta 6$ integrin, a transmembrane adhesion protein (Hynes, 1992) are known to be increased in invasive SCCs (Breuss et al, 1995; Jones et al, 1997; Ramos et al, 1997). Angiogenesis is crucial for tumour growth (Folkman et al, 1963) and metastasis (Folkman, 1990) but the role of angiogenesis is still controversial in oral SCC (Gasparini et al, 1993; Leedy et al, 1994; Hogmo et al, 1999; Macluskey et al, 2000 ) and thus deserves further investigation. MMPs cleave almost all extracellular matrix proteins but differ in substrate specificity. These enzymes can be divided into the collagenases (MMP-1, -8 and -13 ), gelatinases (MMP-2 and -9), stromelysins (MMP-3, -10 and -11), matrilysins (MMP-7 and -26), membrane-type MMPs and other MMPs (Overall and Lopez-Otin, 2002). Previous studies have shown inconsistent results with the expression of various MMPs and the outcome of the patients with oral carcinomas. 
However, in virtually all these previous studies, a heterogenous set of tumours have been analysed and therefore the results may not be comparable (Guttman et al, 2004; Ruokolainen et al, 2004). Identification of any of these factors as a potential prognostic marker would be useful for estimating the behaviour of the tumour and the survival of the patient with SCC in the mobile tongue. In this work, we provide evidence that collagenase-2 (MMP-8) is a protective factor in mobile tongue SCC. Furthermore, and by using mice deficient in this metalloproteinase and oral carcinoma cells producing MMP-8, we examine putative molecular and cellular mechanisms underlying the protective effect of this enzyme in tongue cancer.

\section{MATERIALS AND METHODS}

\section{Patients}

All 90 patients treated surgically (with at least $5 \mathrm{~mm}$ histological margins) at the Oulu University hospital with diagnosed mobile tongue SCC during the years 1981-2001 were included in this study. This tertiary care centre provides primary treatment for all cancer patients in the two northernmost provinces of Finland, covering a population of $\sim 650000$ inhabitants. The patients $(47$ males, 43 females) were 26-99 years of age at the diagnosis of SCC (median 62 years). The following tumour-related factors were collected from the hospital files: tumour grade according to the classification (Pindborg et al 1987) and TNM stage of the tumour (International Union Against Cancer, 2002). The patient's present status (alive or dead, and the cause of death) was confirmed from the death statistics of the statistics of Finland. Completely resected carcinoma specimens were routinely fixed in $10 \%$ formalin, paraffin-embedded and stained with hematoxylin-eosin (HE) for histopathological diagnoses. The study was approved by the Ethical Committee of the Faculty of Medicine, University of Oulu.

\section{Animals}

MMP-8 knockout mice were generated by gene targeting as previously described (Balbin et al, 2003). Wild-type mice (C57BL/6) with a similar genetic background were used as controls. All experiments were approved by and performed according to the recommendations of the Animal Care and Use Committee at the University of Oulu.

\section{Induction of tongue SCC in MMP-8 KO mice}

Forty-seven 13-16-week-old mice were exposed to tongue SCCinducing 4-Nitroquinoline- $N$-oxide (4NQO, Sigma, USA) (Steidler and Reade, 1984; Gannot et al, 2004) dissolved in propylene glycol to a final concentration of $10 \mathrm{mg} \mathrm{ml}^{-1}$. The mice were lightly anaesthetised by Isofluran (Forene ${ }^{\mathrm{R}}$, Abbott Scandinavia, Sweden) inhalation and $4 \mathrm{NQO}$ was smeared to the left dorsal half of the tongue 3 times per week for 12 weeks. The mice were killed at 55 weeks by cervical dislocation after inhalation of $\mathrm{CO}_{2}$. The tongues were dissected and fixed routinely in $10 \%$ formalin for paraffin embedding. Tissue sections were stained with hematoxylin-eosin. Lesions differentiation was analysed and graded into three classes, (1); normal epithelium without any carcinogenic changes (no change), (2); various (mild, moderate, severe) epithelial dysplasias (dysplasia, including four dysplastic papillomas), and (3); SCC (cancer). Histological diagnoses were done for a total of 47 tongues by an expert pathologist.

\section{Cell culture}

Human oral SCC C1-cells (Ylipalosaari et al, 2005) were grown in keratinocyte growth medium including $\alpha$ medium (Gibco BRL, Life
Technologies Inc., Grand Island, NY, USA) containing 10\% fetal bovine serum (EuroClone, Milano, Italy) and supplemented with antibiotics, $1.8 \times 10^{-4} \mathrm{M}$ adenine, $5 \mu \mathrm{g} \mathrm{ml}^{-1}$ insulin, $1 \times 10^{-10} \mathrm{M}$ cholera toxin, $0.5 \mu \mathrm{g} \mathrm{ml}^{-1}$ hydrocortisone, $10 \mathrm{ng} \mathrm{ml}^{-1}$ epidermal growth factor (all from Sigma Chemical Co., St Louis, MO, USA) and $7.5 \%$ sodium bicarbonate. HSC-3 tongue carcinoma cells were grown as previously described (Moilanen et al, 2003). HSC-3 cells were maintained in serum-free medium supplemented with $0.5 \%$ lactalbumin overnight prior to addition of $10 \mathrm{~nm}$ oestrogen $(1,3,5$ (10)-estradien-3 $17 \beta$-diol Steraloids Inc.) overnight. Conditioned media was collected and the cells were rinsed three times with PBS. The cells were incubated on ice for 10 min with $2 \%$ Triton X-100 in PBS for sampling of cell membrane extract. Total proteins were extracted with Trizol ${ }^{\mathbb{R}}$ (Gibco BRL, Life Technologies Inc., Roskilde, Denmark).

\section{RT - PCR}

Total RNA was isolated from HSC-3 cells incubated with or without $10 \mathrm{nM}$ oestrogen (1, 3, 5 (10)-estradien-3 $17 \quad \beta$-diol Steraloids Inc.) using Trizol ${ }^{\circledR}$ (Gibco BRL). RT-PCR was performed as previously described (Moilanen et al, 2002) using random decamers (Ambion Europe Ltd., Cambridgeshire, UK). PCR was performed as previously described using MMP-8 primers producing a band of $352 \mathrm{bp}$ (Moilanen et al, 2002) and $\beta$-actin primers purchased from Ambion Europe Ltd. PCR products were analysed by standard agarose gel electrophoresis.

\section{Antibodies}

The following polyclonal antibodies were used in the immunohistochemical stainings: laminin-5 $\gamma 2$-chain $(1: 1000)$ (Pyke et al, 1995), MMP-8 (1:200) (Hanemaaijer et al, 1997), MMP-9 (1:1000, Neomarkers, Fremont, CA, USA), MMP-20 (1:1000) (Väänänen et al, 2001), MMP-28 (1:500) (Lohi et al, 2001) and factor VIII (1:800, Dako A/S, Glostrup, Denmark). MMP-2 (1:2000, Suomen Bioanalytiikka, SBA, Turku, Finland), MMP-7 (1:80, Calbiochem, La Jolla, CA, USA), integrin $\alpha \mathrm{v} \beta 6\left(6.2 \mathrm{G} 2\right.$ at $0.5 \mu \mathrm{g} \mathrm{ml}^{-1}$ (Weinreb et al, 2004), Biogen Idel, Inc., Cambridge, MA, USA), COX-2 $\left(1 \mu \mathrm{g} \mathrm{ml}^{-1}\right.$, Cayman Chemical, Ann Arbor, Michigan, USA) and CD31 (1:30, DakoCytomation, Glostrup, Denmark) antibodies were monoclonal. ER- $\alpha(1: 100$, MC-20, Santa Cruz Biotechnology Inc., CA, USA) and ER- $\beta$ (1:500, Ab-24, Lab Vision, CA, USA) antibodies were polyclonal.

\section{Immunohistochemical staining}

Immunohistochemical staining was done as previously described (Ylipalosaari et al, 2005). Briefly, paraffin sections were deparaffinised and pretreated. Sections were incubated with the primary antibody overnight at $4{ }^{\circ} \mathrm{C}$. Sections incubated with non-immune rabbit (polyclonal) or non-immune mouse (monoclonal) IgGs instead of primary antibodies were used as negative controls. The sections were incubated with biotinylated secondary antibodies and thereafter with Vectastain Elite $\mathrm{ABC}$ reagent (Vector Laboratories, Burlingame, CA, USA). Finally tissue sections were stained with diaminobenzidine (Sigma-Aldrich, St Louis, MO, USA) or 3-amino-9-ethylcarbazole (Zymed, San Francisco, CA, USA) for $10 \mathrm{~min}$. The sections were counterstained with Mayer's haematoxylin (Histolab Products AB, Göteborg, Sweden). C1 carcinoma cells were doublestained with actin and MMP-8 using a method described previously (Ylipalosaari et al, 2005). Bound MMP-8 antibody was visualised with Alexa 488-conjugated antirabbit secondary antibody ( $1: 200$ dilution, Invitrogen Ltd., Paisley, UK) and actin was visualised with TRITC-conjugated phalloidin ( $5 \mathrm{ng} \mathrm{ml}^{-1}$, Sigma). 


\section{In vitro $\mathrm{ER}-\alpha$ and $\mathrm{ER}-\beta$ cleavage assay}

Human recombinant MMP-8 (Chemicon International Inc., Temecula, CA, USA) was tested for the ability to digest human recombinant oestrogen receptor- $\alpha \quad(\mathrm{ER}-\alpha)$ and oestrogen receptor- $\beta$ (ER- $\beta$ ) (Invitrogen, CA, USA). In all $3.1 \mu \mathrm{g}$ of human recombinant ER- $\alpha$ and $4.1 \mu \mathrm{g}$ of human recombinant ER- $\beta$ were used in the assays. The tested enzyme/substrate (E:S) molar ratios were $1: 11$ and $1: 27$ for ER- $\beta$ and $1: 5,1: 12$, and $1: 33$ for ER- $\alpha$. The reactions were performed in an incubation buffer $(10 \mathrm{~mm}$ HEPES, $0.15 \mathrm{M} \mathrm{NaCl}, 5 \mathrm{mM} \mathrm{CaCl} 2(\mathrm{pH} 7.4)$ ) in the presence or absence of MMP inhibitor GM6001, $10 \mu \mathrm{M}$ (Ryss Laboratories) at $37^{\circ} \mathrm{C}$ for $22 \mathrm{~h}$. The reactions were stopped by boiling in $4 \times$ electrophoresis sample buffer $(250 \mathrm{~mm}$ Tris-HCL; $8 \%$ SDS; $40 \%$ glycerol; $0.0098 \%$ Bromphenol blue ( $\mathrm{pH} 6.8)$ ) for $4 \mathrm{~min}$. The samples were then subjected to SDS-PAGE and cleavage products were separated in non-reducing conditions. ER- $\alpha$ and ER- $\beta$ were detected by immunoblotting as described.

\section{Western blotting}

Serum-free HSC-3 culture medium was concentrated with $10 \mathrm{~K}$ centrifugal filter tubes (Millipore Bedford, MA, USA). The samples were subjected to $10 \%$ SDS-PAGE gel electrophoresis and thereafter the proteins were transferred to Immobilon P membrane (Millipore). The membrane was blocked with 5\% non-fat milk for $1 \mathrm{~h}$ and incubated with MMP-8 antibody (Santa Cruz Biotechnology Inc., CA, USA) at RT overnight. The membrane was washed and incubated with anti-goat secondary antibody $(1: 1000$, DAKO A/S, Glostrup, Denmark) for $1 \mathrm{~h}$ at RT, washed and incubated with ABComplex/HRP $(1: 1000$, DAKO A/S) for $1 \mathrm{~h}$. The membrane was treated with ECL western blotting detection reagent for $1 \mathrm{~min}$ and then exposed to Hyperfilm-ECL (Amersham Pharmacia Biotech, Buckinghamshire, UK).

The proteins from the cleavage assays were separated by $12 \%$ SDS - PAGE and electrotransferred onto a nitrocellulose membrane (Millipore). To identify the digested fragments, the membranes were incubated overnight with ER- $\alpha$ (MC-20, Santa Cruz Biotechnology Inc., CA, USA) antibody against the $\mathrm{COOH}$-terminal part of the receptor at $2 \mu \mathrm{g} \mathrm{ml}^{-1}$ concentration or ER- $\beta$ (Ab-24, Lab Vision, CA, USA) antibody against the $\mathrm{COOH}$-terminal part of the

Table I The disease-specific five-year mortality from 90 tongue SCC patients

\begin{tabular}{|c|c|c|c|}
\hline Factors & $n$ & 5-year mortality (\%) & $95 \% \mathrm{Cl}$ \\
\hline \multicolumn{4}{|l|}{ Gender } \\
\hline Female & 47 & 22 & $9-35$ \\
\hline Male & 43 & 25 & $10-40$ \\
\hline \multicolumn{4}{|l|}{ Age group } \\
\hline $26-70$ years & 59 & 18 & $7-29$ \\
\hline$>70$ years & 31 & 35 & $15-55$ \\
\hline \multicolumn{4}{|l|}{ Clinical stage ${ }^{a}$} \\
\hline | and || & 51 & 14 & $3-25$ \\
\hline III and IV & 36 & 32 & $15-49$ \\
\hline \multicolumn{4}{|c|}{ Malignancy score (Bryne) ${ }^{\mathrm{a}}$} \\
\hline Low score & 22 & 5 & $0-14$ \\
\hline High score & 65 & 31 & $18-44$ \\
\hline \multicolumn{4}{|l|}{ Thickness of SCC } \\
\hline$<6.5 \mathrm{~mm}$ & 33 & 25 & $8-42$ \\
\hline$\geqslant 6.5 \mathrm{~mm}$ & 57 & 27 & $15-39$ \\
\hline
\end{tabular}

receptor at $2.5 \mu \mathrm{g} \mathrm{ml}^{-1}$ concentration. Biotinylated swine anti-rabbit immunoglobulin $\mathrm{G}$ (IgG) secondary antibody (1:1000 dilution) (Dako, Glostrup, Denmark) was then allowed to bind for $1 \mathrm{~h}$. Finally the membranes were incubated with avidin/biotinylated horse radish peroxidise (HRP) complex (Dako) for $1 \mathrm{~h}$ and the immunoreactive proteins were visualised with ECL western blotting detection reagents (Amersham Biosciences, Piscataway, NJ, USA).

\section{Malignancy analysis}

Hematoxylin-eosin-stained sections were used for Bryne malignancy score analysis (Bryne et al, 1992) and for measuring the thickest SCC area. Malignancy score was calculated by determining five morphological features (degree of keratinisation, nuclear polymorphism, number of mitoses, pattern of invasion and lymphoplasmacytic infiltration) from each section and by giving a score $(1-4)$ to each feature. The separate values were then summed up into the final malignancy score $(5-20)$. Samples were

Table 2 The disease-specific five-year mortality from 80-84 tongue SCC patients for histological prognostic factors

\begin{tabular}{|c|c|c|c|}
\hline Factors & $n$ & $\begin{array}{c}\text { 5-year } \\
\text { mortality (\%) }\end{array}$ & $95 \% \mathrm{Cl}$ \\
\hline \multicolumn{4}{|l|}{ Microvessel density } \\
\hline \multicolumn{4}{|l|}{ Inside carcinoma islands } \\
\hline Slight & 26 & 25 & $5-45$ \\
\hline Moderate or abundant & 58 & 25 & $13-37$ \\
\hline \multicolumn{4}{|l|}{ Carcinoma marginals } \\
\hline Slight & 29 & 27 & $7-47$ \\
\hline Moderate or abundant & 54 & 24 & $12-36$ \\
\hline \multicolumn{4}{|l|}{ 'Normal looking' mesenchymal tissue } \\
\hline Slight & 36 & 30 & $14-46$ \\
\hline Moderate or abundant & 47 & 20 & $7-33$ \\
\hline \multicolumn{4}{|l|}{ Expression of COX-2 } \\
\hline \multicolumn{4}{|l|}{ Overview ( $\times 100$ magnification) } \\
\hline$<1 \%$ positively stained cells & 40 & 25 & $10-40$ \\
\hline - $-50 \%$ positively stained cells & 44 & 21 & $7-35$ \\
\hline \multicolumn{4}{|l|}{$\begin{array}{l}\text { Detailed view from 'hot spots' } \\
\text { ( } \times 400 \text { magnification) }\end{array}$} \\
\hline$<1 \%$ positively stained cells & 25 & 28 & $8-48$ \\
\hline I- $10 \%$ positively stained cells & 28 & 14 & $\mid-27$ \\
\hline$>10 \%$ positively stained cells & 31 & 29 & $10-48$ \\
\hline \multicolumn{4}{|l|}{ Expression of laminin-5 $\gamma 2$-chain } \\
\hline \multicolumn{4}{|l|}{ Overview ( $\times 100$ magnification) } \\
\hline \multicolumn{4}{|l|}{ No staining in cancer cells } \\
\hline$<40 \%$ of the tumour area & 63 & 19 & $8-30$ \\
\hline$\geqslant 40 \%$ of the tumour area & 20 & 31 & $10-52$ \\
\hline \multicolumn{4}{|c|}{ Cytoplasmic staining in cancer cells } \\
\hline$<40 \%$ of the tumour area & 57 & 17 & $6-28$ \\
\hline$\geqslant 40 \%$ of the tumour area & 26 & 36 & $13-59$ \\
\hline \multicolumn{4}{|l|}{ Staining in basement membrane } \\
\hline$<40 \%$ of the tumour area & 23 & 27 & $6-48$ \\
\hline$\geqslant 40 \%$ of the tumour area & 60 & 21 & $10-32$ \\
\hline \multirow{2}{*}{\multicolumn{4}{|c|}{$\begin{array}{l}\text { Detailed view from 'hot spots' } \\
\text { ( } \times 400 \text { magnification) }\end{array}$}} \\
\hline & & & \\
\hline \multicolumn{4}{|l|}{ Negatively stained cells } \\
\hline$<50 \%$ of all cancer cells & 23 & 17 & $0-35$ \\
\hline$\geqslant 50 \%$ of all cancer cells & 60 & 24 & $12-36$ \\
\hline \multicolumn{4}{|l|}{ Positively stained cells } \\
\hline$<50 \%$ of all cancer cells & 10 & 12 & $0-36$ \\
\hline$\geqslant 50 \%$ of all cancer cells & 73 & 23 & $12-34$ \\
\hline \multicolumn{4}{|l|}{ Expression of $\alpha v \beta 6$-integrin (score $0-7$ ) } \\
\hline 0 & 7 & 31 & $0-69$ \\
\hline $3-5$ & 28 & 12 & $0-25$ \\
\hline $6-7$ & 45 & 29 & $14-44$ \\
\hline
\end{tabular}


divided into two categories: low (5-10) and high (11-20) Bryne score. Thickness of the SCC was determined from the sections by measuring the thickest SCC area with Leica microscope using Leica IM50 Image Manager program. The sections were divided into two groups: those under $6.5 \mathrm{~mm}$ and those $6.5 \mathrm{~mm}$ or over.

\section{Immunohistochemical evaluations}

All histological evaluations were done at least two times by two to three calibrated investigators without the knowledge of the clinical information of the patients. For microvascular density assessment a method described previously (Weidner et al, 1991) was used with slight modifications. Briefly, the most highly vascularised areas ('hot spots') based on both factor VIII and CD31 stainings were selected and counted from three different areas: (i) inside carcinoma islands, (ii) carcinoma marginals and (iii) at the edge of the slide, 'normal looking' mesenchymal tissue. Cases were divided into three groups: slight, moderate and abundant microvascular density. The levels of COX-2 expression were classified first with low magnification and then with high magnification as follows; grade $0:<1 \%$, grade $2: 1-10 \%$, grade 3: $>10-50 \%$ and grade $4:>50 \%$ of tumour cells. Immunohistochemical staining for the laminin-5 $\gamma 2$-chain was evaluated by dividing each slide into negative $(\mathrm{N}$; no staining within cancer cells), positive ( $\mathrm{P}$; cytoplasmic staining within cancer cells) and basement membrane (BM; the tumour nest periphery was partly or circumferentially stained) areas. Parts of different areas were categorised as follows: 1: $<20 \%, 2: 20-40 \%, 3: 40-60 \%, 4$ : $60-80 \%$ and $5: 80-100 \%$ of the analysed tumour areas. In addition $\mathrm{N}$ and $\mathrm{P}$ areas separately were analysed with high magnification as follows: 1 : $<25 \%, 2: 25-50 \%, 3: 50-75 \%$, and $4: 75-100 \%$ of all tumour cells. The levels of $\alpha \mathrm{v} \beta 6$-integrin expression were classified as follows: $0=$ no positive staining, $1=$ slight positive staining, $2=$ medium positive staining and $3=$ strong positive staining in carcinoma cells. The percentage of positively stained cells of the tumour was categorised as follows: $0:<1 \%, 1: 1-25 \%, 2: 26-50 \%$, 3: $51-75 \%$ and $4: 76-100 \%$. Finally the score $(0-7)$ was calculated by summarising the value of intensity and the category of positively stained cells. Immunostainings for MMPs were evaluated using MMP-2, MMP-7, MMP-8, MMP-9, MMP-20 and MMP-28 antibodies, respectively. The staining intensity and the proportion of the positively stained cells were quantified using a method described previously (Bachmeier et al, 2000). Briefly, a five-step grading score was used for the proportion of positively stained carcinoma cells as follows; score $0:<1$ cell, score $1: 1$ to $<25$ cells, score 2: 25 to $<50$ cells, score 3: 50 to $<75$ cells and score 4: $>75$ cells. A four-step grading was used for the staining intensity of carcinoma cells as follows; score 0: no positive staining, score 1: weak positive staining, score 2: moderate staining, score 3: strong staining intensity. With MMP-8 and MMP-9 antibodies positively stained cancer cells and positively stained inflammatory cells surrounding the carcinoma islands were counted separately, whereas with MMP-2 and MMP-7 antibodies only positively stained cancer cells were counted. For inflammatory cells only the amount of stained cells was counted, that is, no grading score was used. MMP-20 was excluded from the analysis due to the small number of stained carcinoma cells. The score was calculated by multiplying the mean value of positively stained cells and the mean value of staining intensity. The levels of ER- $\beta$ expression were classified as follows: $0=$ no positive staining, $1=$ slight positive staining, $2=$ medium positive staining and $3=$ strong positive staining in carcinoma cells and also in inflammatory cells.

\section{Statistical analysis}

Five-year mortalities from SCC itself (with 95\% confidence intervals, CI) in various subgroups were estimated by the
Kaplan-Meier method. The relative hazards of death from SCC (and 95\% CIs) associated with each marker under study were estimated by the Cox proportional hazards regression model, adjusting for the main known prognostic factors (age, sex, and TNM stage of the tumour). Mutual bivariate associations between the various markers were evaluated by computing odds ratios (OR with $95 \%$ CIs) for pairs of the dichotomised versions of these variables. The response variable in the mice experiment had three ordered categories: no change, dysplasia, and cancer, but it was dichotomised by pooling dysplasias and cancer into one category. The differences in proportion of developing dysplasia or cancer between the MMP-8 knockout mice and the wild-type C57BL/6 mice, were estimated separately for males and females. This analysis was performed using the function twoby 2 in the package Epi, version 0.7.0 (Carstensen et al, 2007) attached with the $\mathrm{R}$ environment for statistical computing and graphics, version 2.6.0 (R Development Core Team, 2007). All the other statistical analyses were performed using the SPSS software version 12.0.1.

\section{RESULTS}

The overall mortality from the tongue cancer up to 5 years following the diagnosis of the SCC was $23 \%$. Case fatality was generally higher among older patients, those with a more advanced clinical stage, and/or with a higher than average Bryne malignancy score, but thickness of the tumour did not predict the outcome

Table 3 The disease-specific five-year mortality from 80-84 tongue cancer for histological prognostic factors

\begin{tabular}{|c|c|c|c|}
\hline Factors & $n$ & $\begin{array}{c}\text { 5-year } \\
\text { mortality (\%) }\end{array}$ & $95 \% \mathrm{Cl}$ \\
\hline \multicolumn{4}{|l|}{ MMP-2 in cancer cells, score } \\
\hline$<0.32$ & 54 & 28 & $|5-4|$ \\
\hline$\geqslant 0.32$ & 30 & 15 & $1-29$ \\
\hline \multicolumn{4}{|l|}{ MMP-7 in cancer cells, score } \\
\hline$<1.84$ & 52 & 24 & $11-37$ \\
\hline$\geqslant 1.84$ & 21 & 26 & $6-46$ \\
\hline \multicolumn{4}{|l|}{ MMP-8 in cancer cells, score } \\
\hline$<0.78$ & 52 & 31 & $17-45$ \\
\hline$\geqslant 0.78$ & 31 & 11 & $0-23$ \\
\hline \multicolumn{4}{|l|}{ MMP-8 in inflammatory cells } \\
\hline$<0.08$ & 42 & 24 & $10-38$ \\
\hline$\geqslant 0.08$ & 41 & 24 & $10-38$ \\
\hline \multicolumn{4}{|l|}{ MMP-9 in cancer cells, score } \\
\hline$<2.62$ & 53 & 29 & $15-43$ \\
\hline$\geqslant 2.62$ & 30 & 19 & $4-34$ \\
\hline \multicolumn{4}{|l|}{ MMP-9 in inflammatory cells } \\
\hline$<10.20$ & 41 & 32 & $16-48$ \\
\hline$\geqslant 10.20$ & 42 & 18 & $5-31$ \\
\hline \multicolumn{4}{|l|}{ MMP-28 in cancer cells, score } \\
\hline$<0.09$ & 58 & 26 & $13-39$ \\
\hline$\geqslant 0.09$ & 24 & 19 & $2-36$ \\
\hline \multicolumn{4}{|l|}{$E R-\beta$ in cancer cells, staining intensity } \\
\hline $0-1=$ No or slight positive staining & 31 & 19 & $4-35$ \\
\hline $\begin{array}{l}2-3=\text { Medium or strong positive } \\
\text { staining }\end{array}$ & 35 & 29 & $12-45$ \\
\hline \multicolumn{4}{|c|}{$E R-\beta$ in inflammatory cells, staining intensity } \\
\hline $0-\mathrm{I}=$ No or slight positive staining & 34 & 25 & $8-41$ \\
\hline $\begin{array}{l}2-3=\text { Medium or strong positive } \\
\text { staining }\end{array}$ & 33 & 23 & $8-38$ \\
\hline
\end{tabular}


(Table 1). There was no evidence for microvascular density or expression of factors such as COX-2, laminin-5 $\gamma 2$-chain and $\alpha \mathrm{v} \beta 6$ integrin (Table 2) as being associated with the prognosis. By contrast, it appeared that subjects with positive immunostaining for MMP- $-2,-8,-9$, or -28 in the cancer cells or MMP-9 or ER- $\beta$ in inflammatory cells would have a better prognosis than other patients (Table 3). However, the statistical evidence in support of these observed contrasts was weak.

Bivariate associations between the various markers were also analysed. High Bryne malignancy score value predicted high level of $\alpha \mathrm{v} \beta 6$-integrin (OR 2.9, 95\% CI 1.1-8.2), but MMP-9 and COX2 levels in carcinoma cells (OR 0.17, 95\% CI $0.03-0.78$; and OR 0.19, $95 \%$ CI $0.06-0.65$, respectively) were negatively associated with high Bryne category. Likewise, high level of COX-2 predicted high MMP-9 level in carcinoma cells (OR 2.7, 95\% CI 1.0-7.3), but laminin-5 $\gamma 2$-chain staining within carcinoma cells was inversely associated with MMP-9 expression (OR 0.22, 95\% CI 0.08-0.61).

Further analysis revealed that the only statistically significant marker for case fatality was MMP-8 (Table 3). Patients with tumours lacking MMP-8 expression in cancer cells had a relative SCC mortality rate of $3.70(95 \%$ CI $1.04-12.5)$ compared to patients with some MMP-8 positive immunostaining, when adjusted for age, sex, and stage of tumour (TNM) by the proportional hazards model. MMP-8 or MMP-9 expression in inflammatory cells was not associated with survival (Table 3 ). In addition, for all evaluated factors only MMP- 8 came up with Cox's regression model when age, gender and stage were installed as main variables. Interestingly, positive MMP-8 expression and improved survival also showed a tendency to be more prominent in female tongue cancer patients than in male tongue cancer patients, but this difference was not found to be statistically significant. The mortality of patients with no positive MMP-8 immunostaining also increased over time during the 5-year period (Figure 1). The associations of MMP-8 with gender, oestrogen receptor levels (separately in cancer cells and in inflammatory cells), tumour thickness, TNM stage, and tumour grading were not statistically significant.

To test the hypothesis that MMP- 8 plays a protective role in tongue SCC, 23 MMP-8 knockout (KO) and 24 wild-type C57BL/6 mice were subjected to chemical carcinogenesis with 4-Nitroquino-

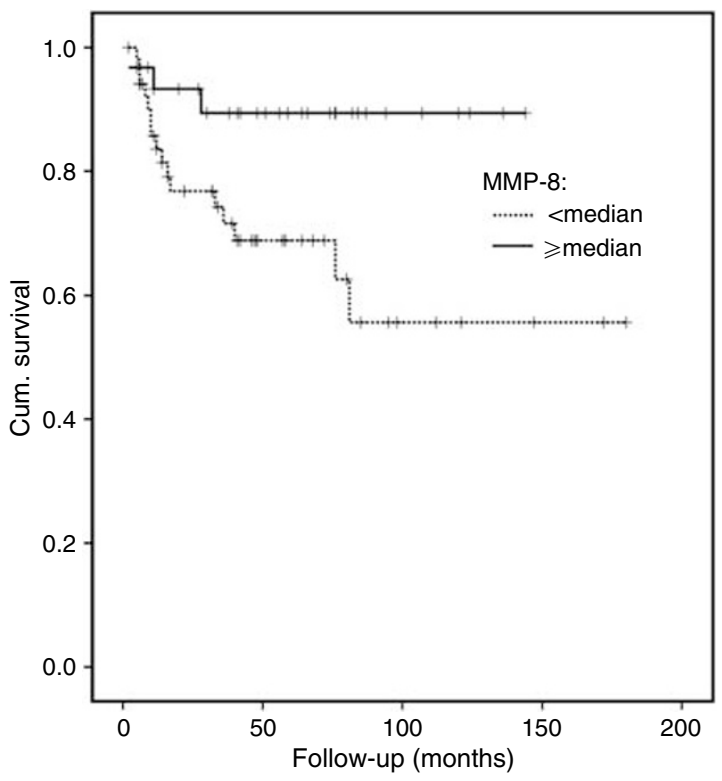

Figure I MMP-8 expression in carcinoma cells correlates with improved survival of tongue cancer analysed with the Kaplan-Meier method. line- $N$-oxide (4NQO) for 12 weeks. Half (6/12) of the MMP-8 KO female mice in contrast to none of the 12 wild-type C57BL/6 female mice developed tongue cancer during the experiment (Table 4, Figure 2). Similarly, dysplasias were more frequent in the tongues of MMP-8 KO female mice (4/12) than in wild-type mice (2/12). In male mice no difference in carcinoma development was found between the mouse groups. There was a strong statistical support to the observation that the MMP-8 KO female mice developed tongue cancer more often than the wild-type mice. The estimated proportion of female MMP-8 KO mice developing either dysplasia or carcinoma was 67 percent points higher than that of the female wild-type mice ( 83 vs $17 \%$; $95 \%$ CI for the difference in proportions: +21 to +85 percent points). In male mice the same contrast was observed to be 20 percent points $(95 \% \mathrm{CI}-21$ to +55 percent points).

MMP-8 expression was further analysed in cultured oral SCC cells by confocal immunofluorescence, which localised MMP-8 immunoreactivity mainly to the tongue carcinoma cell membranes and to subcellular granules. Lack of MMP-8 was found to have different effect on male and female mice when experimental SCC was induced. We therefore investigated the effect of oestrogen on HSC-3 cells. Molecular forms of MMP-8 were identified from HSC-3 tongue carcinoma cells by using western blotting which demonstrated a $75 \mathrm{kDa}$ species in HSC-3 cell membrane extracts. Oestrogen treatment induced expression of a $75 \mathrm{kDa}$ MMP- 8 species in HSC-3 cells as evidenced by western blotting. To verify this observation we also performed MMP-8 RT - PCR from HSC-3 cells incubated with or without $10 \mathrm{nM}$ oestrogen overnight and found that MMP- 8 mRNA was undetectable in resting HSC-3 cells while oestrogen treatment induced MMP-8 mRNA expression (Figure 3).

Because oestrogen acts through the oestrogen receptors, we investigated the expression of ERs in tongue SCCs. Both oestrogen receptor- $\alpha(\mathrm{ER}-\alpha)$ and oestrogen receptor- $\beta$ (ER- $\beta$ ) were expressed in human and mouse tongue SCC cells as detected by immunohistochemical methods (Figure 4). ER- $\beta$ expression was found to weakly correlate with a better prognosis (Table 3).

To test, whether MMP- 8 cleaves ER- $\alpha$ or ER- $\beta$, and thus could have effect on their function, we performed an in vitro cleavage assay using purified recombinant MMP-8 and ERs. MMP-8 was found to cleave ER- $\alpha$ in vitro dose dependently (Figure 5). Two cleavage products of full length ER- $\alpha(66 \mathrm{kDa})$ were detected, with the approximate molecular weights of 44 and $26 \mathrm{kDa}$ by western immunoblotting with an ER- $\alpha$ antibody. The intermediate cleavage product of $44 \mathrm{kDa}$ was detected only with the enzyme/substrate molar ratio $1: 5$ (Figure 5A). Only minor cleavage of ER- $\beta$ by MMP-8 could be detected (Figure 5B, only the result from E:S ratios $1: 11$ shown). Approximately $20 \mathrm{kDa}$ and $45 \mathrm{kDa}$ cleavage products of monomeric $53 \mathrm{kDa}$ ER- $\beta$ increased, and around $100 \mathrm{kDa}$ dimeric and $200 \mathrm{kDa}$ higher molecular weight forms of ER- $\beta$ slightly diminished after incubating with MMP-8 (Figure 5B). The broad-spectrum MMP inhibitor GM6001 abolished the ERs degradation by MMP-8 (not shown).

Table 4 Histological incidence of lesions in 4NQO-treated tongue sections from MMP-8 $\mathrm{KO}$ and wild type mice

\begin{tabular}{llcccc}
\hline \multicolumn{7}{c}{ Response } \\
\hline Sex & Strain & No change & Dysplasia & Carcinoma & Total \\
\hline Male & C57BL/6 & 9 & 2 & 1 & 12 \\
& MMP-8 KO & 6 & 4 & 1 & 11 \\
Female & C57BL/6 & 10 & 2 & 0 & 12 \\
& MMP-8 KO & 2 & 4 & 6 & 12 \\
\hline
\end{tabular}



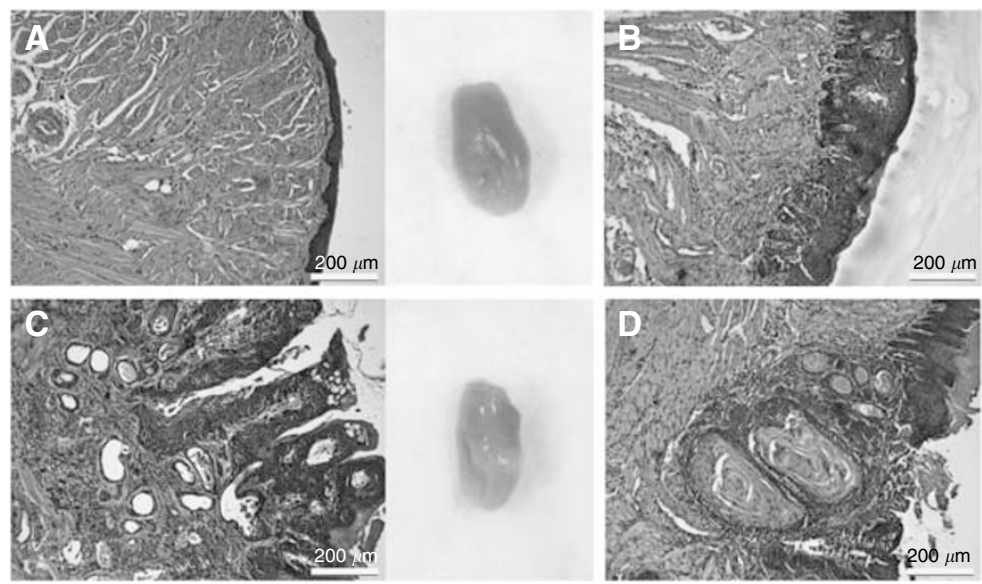

Figure 2 Histopathological and clinical analyses of 4NQO-treated tongues from MMP-8 KO and C57BL/6 mice. (A) Normal C57BL/6 male mouse mucosa stained with hematoxylin and eosin. Clinical tongue on the right. (B) MMP-8 KO male with dysplasia. (C) MMP-8 KO females with invasive SCC. (D) MMP-8 KO females with invasive SCC. Scale bar $=200 \mu \mathrm{m}$.
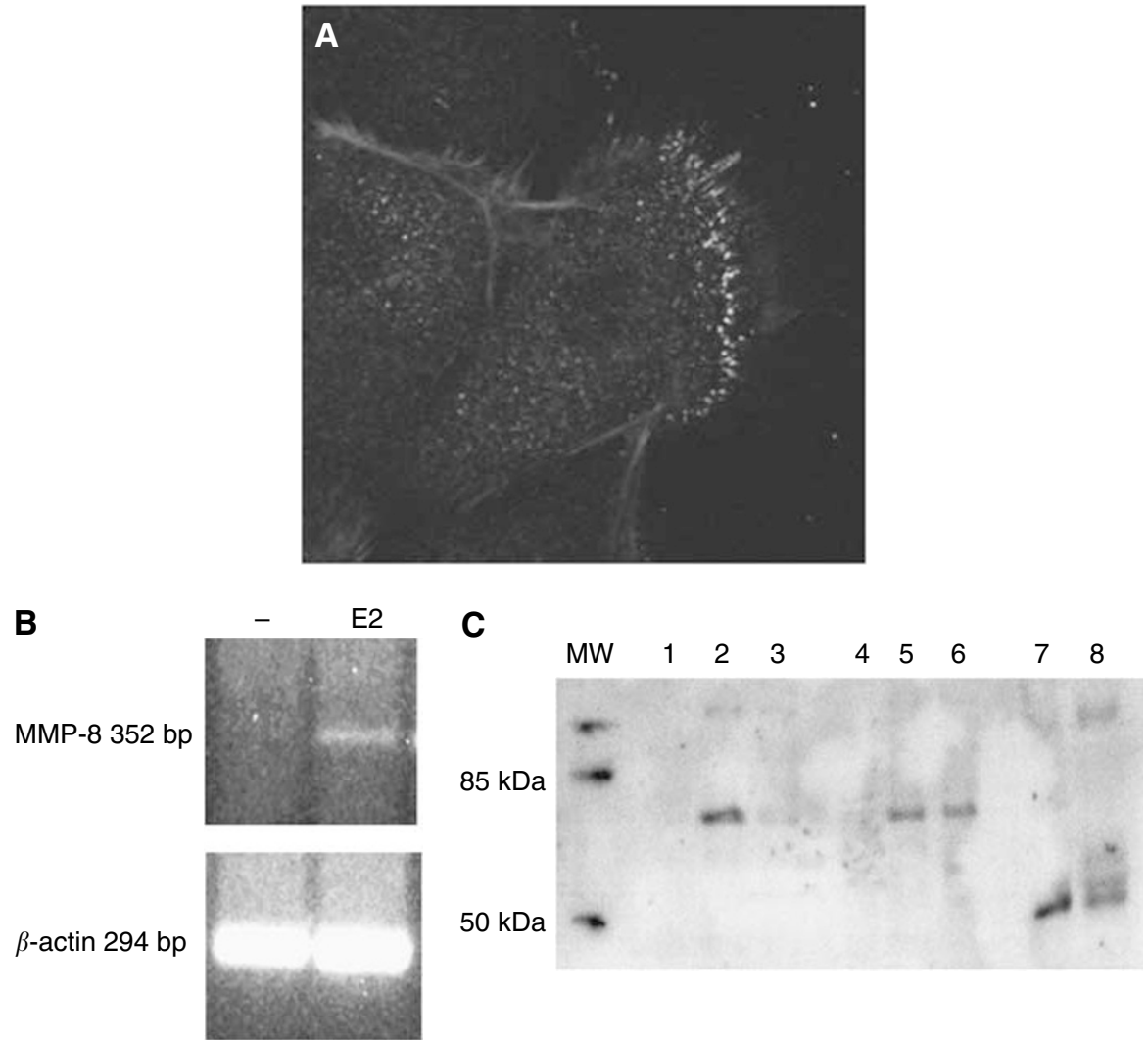

Figure 3 Localisation and molecular forms of MMP-8 in cultured oral carcinoma cells. Localisation of MMP-8 immunoreactivity in oral SCC cell membranes and in intracellular granules is demonstrated in green and red staining demonstrates actin (A). MMP-8 and $\beta$-actin RT-PCR from HSC-3 tongue carcinoma cells incubated with or without $10 \mathrm{nM}$ oestrogen (E2) overnight (B). Molecular sizes of MMP-8 in HSC-3 tongue carcinoma cells analysed by western blotting (C). Lanes I (no E2) and 4 (E2 added) represent concentrated medium where no MMP-8 is detected. Lanes 2 (no E2) and 5 (E2 added) represent the cell membrane extracts where a $75 \mathrm{kDa}$ species can be seen. Lanes 3 (no E2) and 6 (E2 added) are total proteins where a $75 \mathrm{kDa}$ species is visible only after E2 treatment. Lane 7 is odontoblast medium and lane 8 human saliva used as positive controls where a $58 \mathrm{kDa}$ form of MMP-8 can be detected.

\section{DISCUSSION}

Our investigation was based upon a unique population-based collection of 90 surgically treated SCC resection samples of the mobile tongue. Treatment of the patients in Northern Finland is very effective; the overall mortality from the disease up to 5 years was only $23 \%$ in this study, while it generally varies within about
$40-55 \%$ in Finland (Dickman et al, 1999). Worldwide, head and neck cancer is the sixth most common cancer (Hunter et al, 2005). Low mortality in this case may hide the significance of some individual prognostic markers, since patients outcome is most likely affected more by the effective diagnostic and treatment strategies than by any of the biological variables. The prognosis was significantly better in younger patients (26-70 years), in 

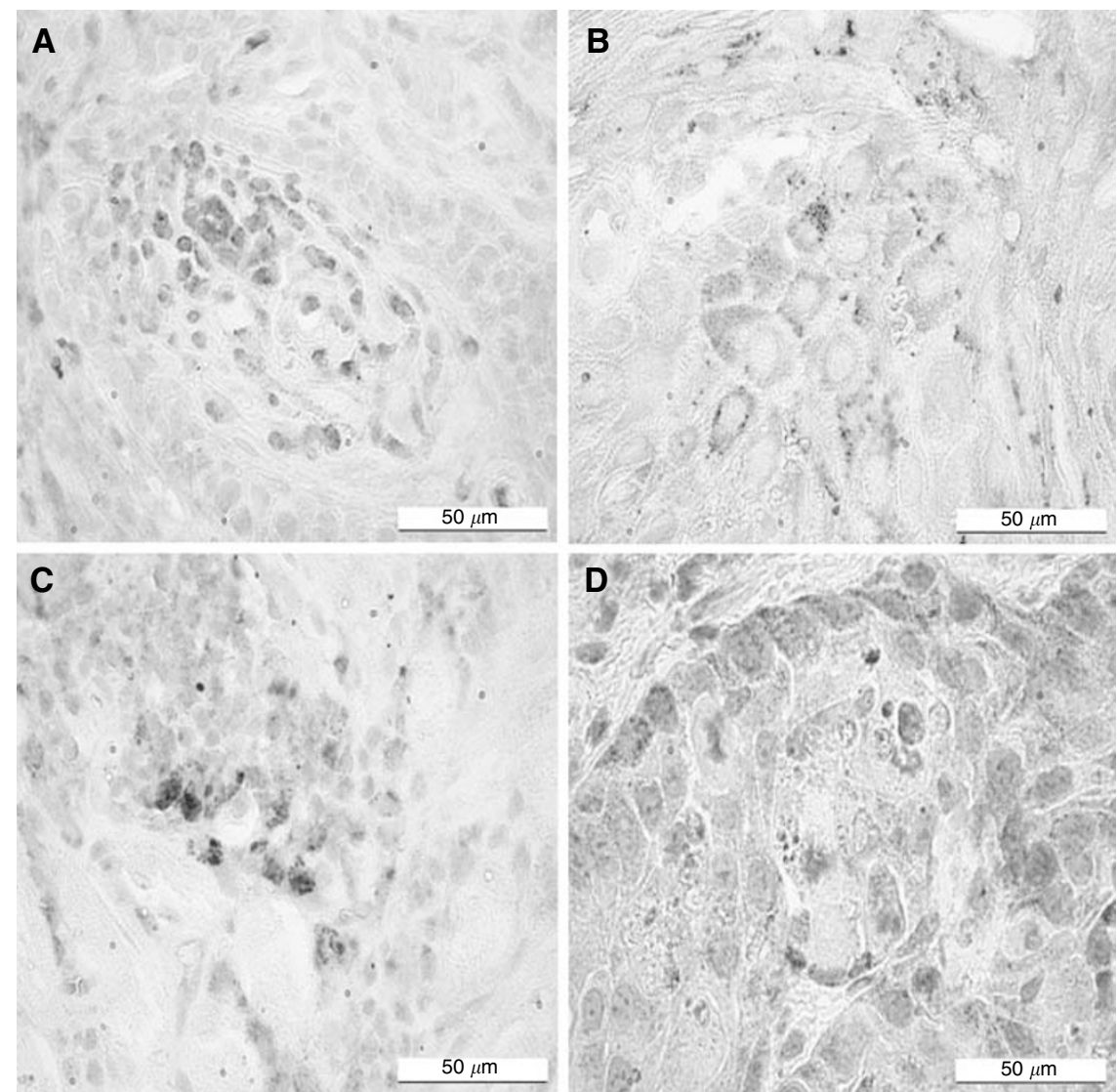

Figure 4 Oestrogen receptor- $\alpha$ and $-\beta$ immunohistochemical staining in tongue squamous cell carcinoma. Nuclear and cytoplasmic ER- $\alpha$ and ER- $\beta$ positivity (red staining) were detected both in mouse and human tongue SCC cells. (A) Mouse SCC stained with ER- $\alpha$ antibody (MC-20). (B) Human SCC stained with ER- $\alpha$ antibody (MC-20) (C) Mouse SCC stained with ER- $\beta$ antibody (ab-24). (D) Human SCC stained with ER- $\beta$ antibody (ab-24). Scale bars $=50 \mu \mathrm{m}$.

patients with lower clinical stages of the tumours (TNM I and II) and in patients with lower (5-10) Bryne's malignancy score as has been shown earlier by us (Kantola et al, 2000) and other investigators (Piffko et al, 1997). Our results were in line with Teixeira et al (1996), who also did not find a correlation between the thickness of the cancer in the deepest tumour areas and outcome of the patients, but in contrast with a study by Charoenrat et al (2003) where tumour thickness and survival of the tongue SCC patients correlated significantly. Also in line with previous tongue SCC studies, we did not observe any association between micro vessel density either within the borders or outside the invasive SCC tissue and prognosis of the patients (Leedy et al, 1994; Hogmo et al, 1999). Unlike Pannone et al (2007), we could not find a correlation between COX-2 expression and survival, but COX-2 expression was negatively associated with high Bryne's category, which is seen as a predictor for poor prognosis (Bryne et al, 1992). Unlike published earlier (Ono et al, 1999; Katoh et al, 2002; Gasparoni et al, 2007), cytoplasmic or basement membrane zone staining for the laminin-5 $\gamma 2$-chain in cancer cells did not correlate with the outcome of the patient in our study. There are several reports showing increased $\alpha \mathrm{v} \beta 6$ integrin expression in invasive SCCs (Breuss et al, 1995; Jones et al, 1997; Ramos et al, 1997), but these findings could not be replicated here, although our results, suffering from wide error margins, were not in any conflict with the previous ones. Over $90 \%$ of our tongue cancers samples did express $\alpha \mathrm{v} \beta 6$ integrin but the expression level did not statistically correlate with the outcome of the patients. However, high level of $\alpha \mathrm{v} \beta 6$ integrin was associated with high Bryne malignancy score category and may thus be linked to more aggressive behaviour and poorer prognosis of the cancer.
MMPs are known to be overexpressed in pathological stages requiring matrix turnover (Overall and Lopez-Otin, 2002). Of the molecules analysed in this study, the statistical evidence was insufficient to make judgments on the association between the expression of MMP-2, $-7,-9$, and -28 with survival from SCC of the tongue. In previous studies, MMP-9 expression is associated with poor prognosis in tongue and also head and neck SCCs (Juarez et al, 1993; Kawamata et al, 1998; Nyberg et al, 2002) but there is also publications where such a correlation has not been found Kim et al, 2006) However, in our bivariate analysis we observed a positive association between MMP-9 and COX-2 levels in carcinoma cells, but negative association with MMP-9 presence and high Bryne category suggesting that MMP-9 in these samples reflects, but not statistically significantly, better prognosis of the disease. In addition, our MMP-28 findings were in the line with Lin et al (2006). We found a slight trend between positive MMP-28 immunostaining and better prognosis of tongue squamous cell carcinoma. By contrast, parallel analysis with MMP-8 revealed that production of this protease was significantly associated with good clinical outcome in tongue cancer patients. Decock et al (2007) showed that genetic variation in the MMP-8 gene could influence breast cancer prognosis. They also noticed that MMP-8 inhibited breast cancer metastasis. These observations are also in the line with previous studies where MMP-8 expression was associated with a better prognosis of skin cancer in mice (Balbin et al, 2003) and a benign behaviour of cultured breast cancer cells (Agarwal et al, 2003). However, Stadlmann et al (2003) found that MMP-8 expression in ovarian cancer was associated with a poorer prognosis. This is probably due to the fact that different cancer types, or species for that matter, cannot always be directly 
A

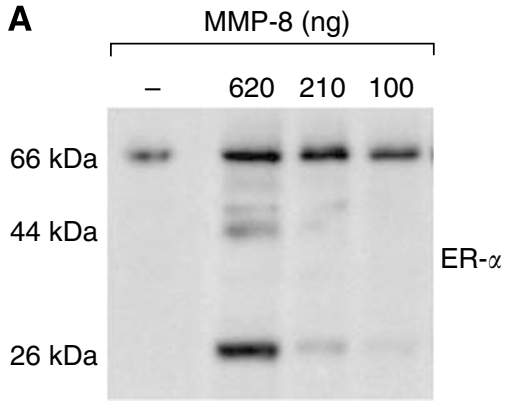

B

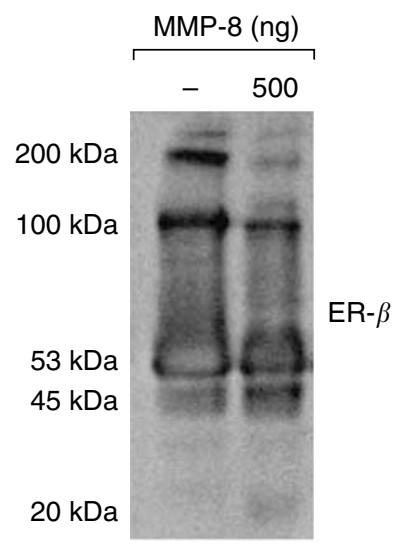

Figure 5 Cleavage of ERs by MMP-8 in vitro. Recombinant MMP-8 was incubated with recombinant ER- $\alpha$ and ER- $\beta$ at different enzyme-substrate ratios. The cleavage fragments were separated by SDS-PAGE and identified by Western immunoblotting using ER-specific antibodies. (A) ER- $\alpha$ was incubated with an increasing amount of MMP-8. The cleavage products of approximately 44 and $26 \mathrm{kDa}$ were detected with ER- $\alpha$ (MC-20) antibody (B). The ER- $\beta$ (ab-24) antibody detected the cleavage products of about 45 and $20 \mathrm{kDa}$. In addition, the higher molecular weight forms of ER- $\beta$ with approximate sizes of 100 and $200 \mathrm{kDa}$ were diminished after incubation with MMP-8.

compared with each other. This is the first study to show that MMP-8 expression in human tongue cancer is significantly linked with prolonged survival. Consistent with this, we also observed that MMP-8 deficient mice were more susceptible to tongue SCC than control mice, this contrast appearing to be more pronounced in females than in male mice. In addition, we found that MMP-8 is cell-membrane associated in cultured tongue carcinoma cells and that oestrogen can induce MMP- 8 mRNA and protein expression in HSC-3 tongue carcinoma cells which could partially explain the differences in cancer susceptibility between the genders. Similarly, oestrogen-induced MMP-26 expression has been associated with improved survival in breast cancer (Savinov et al, 2006). MMP-8 expression was previously linked to positive characteristics in cultured breast cancer cells (Agarwal et al, 2003) and in mouse cancer studies (Balbin et al, 2003). Unlike the MMP-26 gene promoter, the MMP-8 gene promoter does not include an oestrogen receptor element. In contrast, it includes the CCAAT/ enhancer-binding protein (C/EBP) element (Khanna-Gupta et al,
2005). C/EBP has been shown to associate with ER- $\alpha$ and the complex then acts as a transcription factor and can regulate gene promoter activity (Chen et al, 2006). This could explain why oestrogen induces MMP-8 production in HSC-3 cells. Li et al, 2004 found the MMP-26 gene promoter activity to be stimulated by oestrogen through the ERs. In addition, MMP- 26 can cleave ER- $\beta$ in vitro and plays an important antitumorigenic role in hormoneregulated malignancies by regulating the amount of ER- $\beta$ and thus regulating the oestrogen signalling pathway (Savinov et al, 2006). In this study we found, for the first time, that although ER- $\beta$, but not ER- $\alpha$, are expressed in normal oral mucosa (Välimaa et al, 2004) they were both faintly produced in the tongue SCC islands. ER- $\beta$ is expressed by lymphocytes (Törnwall et al, 1999; Ulziibat et al, 2006), and interestingly we found a weak correlation for the expression of ER- $\beta$ in inflammatory cells with prolonged survival. We also found that MMP- 8 can effectively cleave ER- $\alpha$ and some cleavage of ER- $\beta$ in vitro was also detected. Additionally, a dimeric (about $100 \mathrm{kDa}$ ) and a higher molecular weight (around $200 \mathrm{kDa}$ ) form of ER- $\beta$ monomer ( $53 \mathrm{kDa}$ ) diminished after incubating with MMP-8. According to these data, it is possible that MMP-8 cleaves the ER- $\beta$ dimer and complex forms also in vivo. Dimerisation and stability of ER dimers is crucial for oestrogen receptor activation and function as a transcription factor (Tamrazi et al, 2002). These data suggest that MMP-8 protective role could be related to its ability to regulate the amount of ERs and thus regulating oestrogen-signalling pathway during tumour development, especially in hormone-regulated malignancies. This finding also at least partly explains the differences between MMP-8 KO male and female mice cancer susceptibility. Our study now supports these data also in human patients with mobile tongue SCC, the most common type of oral cancer.

In conclusion, based on both human SCC tissue sample analysis and mice in vivo carcinogenesis experiments, our study is the first to provide evidence that carcinoma cell membrane bound MMP-8 should be considered as a protective anti-tumour factor in mobile tongue SCC and its mechanism of action in tumours may be oestrogen related.

\section{ACKNOWLEDGEMENTS}

This study was supported by grants from the Academy of Finland (no 104352, 110070, 108717), the Northern Finland Cancer Foundation, Oulu University KEVO-grants, Helsinki University Central Hospital EVO-grants, Finnish Dental Association of Apollonia and by grants from the Finnish Cultural Foundation and the K Albin Johansson Foundation (E Pirilä), and CYCITSpain and European Union Cancer Degradome (C Lopez-Otin). We thank Ms Merja Tyynismaa for expert technical assistance. Ahti Niinimaa (PhD) is acknowledged for his help with statistical analyses. We thank Dr John D Bartlett (Forsyth Institute, Harvard School of Dental Medicine, US) for kindly providing the MMP-20 antibody, Dr Jouko Lohi (University of Helsinki, Finland) for kindly providing the MMP-28 antibody and Dr John Marshall (Tumour Biology Laboratory, Cancer Research UK Clinical Centre, Barts and the London School of Medicine and Dentistry, London, UK) for assisting with immunofluorescence.

\section{REFERENCES}

Agarwal D, Goodison S, Nicholson B, Tarin D, Urquidi V (2003) Expression of matrix metalloproteinase 8 (MMP-8) and tyrosinase-related protein-1 (TYRP-1) correlates with the absence of metastasis in an isogenic human breast cancer model. Differentiation 71: 114-125

Alho OP, Kantola S, Pirkola U, Laara E, Jokinen K, Pukkala E (1999) Cancer of the mobile tongue in Finland - increasing incidence, but improved survival. Acta Oncol 38: 1021-1024
Bachmeier BE, Nerlich AG, Boukamp P, Lichtinghagen R, Tschesche H, Fritz H, Fink E (2000) Human keratinocyte cell lines differ in the expression of the collagenolytic matrix metalloproteinases- $1,-8$, and -13 and of TIMP-1. Biol Chem 381: 509-516

Balbin M, Fueyo A, Tester AM, Pendas AM, Pitiot AS, Astudillo A, Overall CM, Shapiro SD, Lopez-Otin C (2003) Loss of collagenase-2 confers increased skin tumor susceptibility to male mice. Nat Genet 35: 252-257 
Bettendorf O, Piffko J, Bankfalvi A (2004) Prognostic and predictive factors in oral squamous cell cancer: important tools for planning individual therapy? Oral Oncol 40: 110-119

Breuss JM, Gallo J, DeLisser HM, Klimanskaya IV, Folkesson HG, Pittet JF, Nishimura SL, Aldape K, Landers DV, Carpenter W (1995) Expression of the beta 6 integrin subunit in development, neoplasia and tissue repair suggests a role in epithelial remodeling. J Cell Sci 108(Part 6): 2241-2251

Brinkman BM, Wong DT (2006) Disease mechanism and biomarkers of oral squamous cell carcinoma. Curr Opin Oncol 18: 228-233

Bryne M, Koppang HS, Lilleng R, Kjaerheim A (1992) Malignancy grading of the deep invasive margins of oral squamous cell carcinomas has high prognostic value. J Pathol 166: 375-381

Carstensen B, Plummer M, Läärä E, Hills M, Clayton D, Myatt M (2007) Epi: a package for statistical analysis in epidemiology. $\mathrm{R}$ package version 0.7.0, URL: http://www.pubhealth.ku.dk/ bxc/Epi/

Charoenrat P, Pillai G, Patel S, Fisher C, Archer D, Eccles S, Rhys-Evans P (2003) Tumour thickness predicts cervical nodal metastases and survival in early oral tongue cancer. Oral Oncol 39: 386-390

Chen YH, Lee MJ, Chang HH, Hung PF, Kao YH (2006) 17 beta-estradiol stimulates resistin gene expression in 3T3-L1 adipocytes via the estrogen receptor, extracellularly regulated kinase, and CCAAT/enhancer binding protein-alpha pathways. Endocrinology 147: 4496-4504

Decock J, Long JR, Laxton RC, Shu XO, Hodgkinson C, Hendrickx W, Pearce EG, Gao YT, Pereira AC, Paridaens R, Zheng W, Shu Y (2007) Association of matrix metalloproteinase-8 gene variation with breast cancer prognosis. Cancer Res 67: 10214-10221

Dickman PW, Hakulinen T, Luostarinen T, Pukkala E, Sankila R, Soderman B, Teppo L (1999) Survival of cancer patients in Finland 1955-1994. Acta Oncol 38(Suppl 12): 1-103

Folkman J (1990) What is the evidence that tumors are angiogenesis dependent? J Natl Cancer Inst 82: 4-6

Folkman J, Long Jr DM, Becker FF (1963) Growth and metastasis of tumor in organ culture. Cancer 16: 453-467

Gannot G, Buchner A, Keisari Y (2004) Interaction between the immune system and tongue squamous cell carcinoma induced by 4-nitroquinoline N-oxide in mice. Oral Oncol 40: 287-297

Gasparini G, Weidner N, Maluta S, Pozza F, Boracchi P, Mezzetti M, Testolin A, Bevilacqua P (1993) Intratumoral microvessel density and p53 protein: correlation with metastasis in head-and-neck squamous-cell carcinoma. Int J Cancer 55: 739-744

Gasparoni A, Della Casa M, Milillo L, Lorenzini G, Rubini C, Urso R, Lo Muzio L (2007) Prognostic value of differential expression of laminin-5 gamma2 in oral squamous cell carcinomas: correlation with survival. Oncol Rep 4: 793-800

Guttman D, Stern Y, Shpitzer T, Ulanovski D, Druzd T, Feinmesser R (2004) Expression of MMP-9, TIMP-1, CD-34 and factor-8 as prognostic markers for squamous cell carcinoma of the tongue. Oral Oncol 40: $798-803$

Hanemaaijer R, Sorsa T, Konttinen YT, Ding Y, Sutinen M, Visser H, van Hinsbergh VW, Helaakoski T, Kainulainen T, Rönkä H, Tschesche $\mathrm{H}$, Salo T (1997) Matrix metalloproteinase-8 is expressed in rheumatoid synovial fibroblasts and endothelial cells. Regulation by tumor necrosis factor-alpha and doxycycline. J Biol Chem 272: 31504-31509

Hogmo A, Kuylenstierna R, Lindholm J, Munck-Wikland E (1999) Predictive value of malignancy grading systems, DNA content, p53 and angiogenesis for stage I tongue carcinomas. J Clin Pathol 52: 35-40

Hunter KD, Parkinson EK, Harrison PR (2005) Profiling early head and neck cancer. Nat Rev Cancer 5: 127-135

Hynes RO (1992) Integrins: versatility, modulation, and signalling in cell adhesion. Cell 69: 11-25

International Union Against Cancer (2002) TNM classification of malignant tumours

Jones J, Watt FM, Speight PM (1997) Changes in the expression of alpha v integrins in oral squamous cell carcinomas. J Oral Pathol Med 26: 63-68

Juarez J, Clayman G, Nakajima M, Tanabe KK, Saya H, Nicolson GL, Boyd D (1993) Role and regulation of expression of 92-kDa type-IV collagenase (MMP-9) in 2 invasive Squamous cell carcinoma cell lines of the oral cavity. Int J Cancer 55: 10-18

Kantola S, Parikka M, Jokinen K, Hyrynkangs K, Soini Y, Alho OP, Salo T (2000) Prognostic factors in tongue cancer - relative importance of demographic, clinical and histopathological factors. $\mathrm{Br} J$ Cancer 83: 614-619

Katoh K, Nakanishi Y, Akimoto S, Yoshimura K, Takagi M, Sakamoto M, Hirohashi S (2002) Correlation between laminin-5 gamma2 chain expression and epidermal growth factor receptor expression and its clinicopathological significance in squamous cell carcinoma of the tongue. Oncology 62: 318-326

Kawamata H, Uchida D, Hamano H, Kimura-Yanagawa T, Nakashiro KI, Hino S, Omotehara F, Yoshida H, Sato M (1998) Active-MMP2 in cancer cells nests of oral cancer patients: correlation with lymph node metastasis. Int J Oncol 13: 699-704

Khanna-Gupta A, Zibello T, Idone V, Sun H, Lekström-Himes J, Berliner N (2005) Human neutrophil collagenase expression is C/EBP-dependent during myeloid development. Exp Hematol 33: 42-52

Kim SH, Cho NH, Kim K, Lee JS, Koo BS, Kim JH, Chang JH, Choi EC (2006) Correlations of oral tongue cancer invasion with matrix metalloproteinases (MMPs) and vascular endothelial growth factor (VEGF) expression. J Surg Oncol 93: 330-337

Leedy DA, Trune DR, Kronz JD, Weidner N, Cohen JI (1994) Tumor angiogenesis, the p53 antigen, and cervical metastasis in squamous carcinoma of the tongue. Otolaryngol Head Neck Surg 111: 417-422

Li W, Savinov AY, Rozanov DV, Golubkov VS, Hedayat H, Postnova TI, Golubkova NV, Linli Y, Krajewski S, Strongin AY (2004) Matrix metalloproteinase-26 is associated with estrogen-dependent malignancies and targets alpha1-antitrypsin serpin. Cancer Res 64: 8657-8665

Lin MH, Liu SY, Su HJ, Liu YC (2006) Functional role of matrix metalloproteinase-28 in the oral squamous cell carcinoma. Oral Oncol 9: $907-913$

Lohi J, Wilson CL, Roby JD, Parks WC (2001) Epilysin, a novel human matrix metalloproteinase (MMP-28) expressed in testis and keratinocytes and in response to injury. J Biol Chem 276: 10134-10144

Macluskey M, Chandrachud LM, Pazouki S, Green M, Chisholm DM, Ogden GR, Schor SL, Schor AM (2000) Apoptosis, proliferation, and angiogenesis in oral tissues. Possible relevance to tumour progression. J Patho 191: $368-375$

Moilanen M, Pirila E, Grenman R, Sorsa T, Salo T (2002) Expression and regulation of collagenase-2 (MMP-8) in head and neck squamous cell carcinomas. J Pathol 197: 72-81

Moilanen M, Sorsa T, Stenman M, Nyberg P, Lindy O, Vesterinen J, Paju A, Konttinen YT, Stenman UH, Salo T (2003) Tumor-associated trypsinogen-2 (trypsinogen-2) activates procollagenases (MMP-1, -8, -13) and stromelysin-1 (MMP-3) and degrades type I collagen. Biochemistry 42: $5414-5420$

Nyberg P, Moilanen M, Paju A, Sarin A, Stenman UH, Sorsa T, Salo T (2002) MMP-9 activation by tumor trypsin-2 enhances in vivo invasion of human tongue carcinoma cells. J Dent Res 81: 831-835

Ono Y, Nakanishi Y, Ino Y, Niki T, Yamada T, Yoshimura K, Saikawa M, Nakajima T, Hirohashi S (1999) Clinocopathologic significance of laminin-5 gamma2 chain expression in squamous cell carcinoma of the tongue: immunohistochemical analysis of 67 lesions. Cancer 85: $2315-2321$

Overall CM, Lopez-Otin C (2002) Strategies for MMP inhibition in cancer: innovations for the post-trial era. Nat Rev Cancer 2: 657-672

Pannone G, Sanguedolce F, De Maria S, Farina E, Lo Muzio L, Serpico R, Emanuelli M, Rubini C, De Rosa G, Staibano S, Macchia L, Bufo P (2007) Cyclooxygenase isozymes in oral squamous cell carcinoma: a real-time RT-PCR study with clinic pathological correlations. Int J Immunopathol Pharmacol 2: 317-324

Piffko J, Bankfalvi A, Ofner D, Bryne M, Rasch D, Joos U, Bocker W, Schmid KW (1997) Prognostic value of histobiological factors (malignancy grading and AgNOR content) assessed at the invasive tumour front of oral squamous cell carcinomas. Br J Cancer 75: 1543-1546

Pindborg J, Reichart P, Smith C, Van der Waal I (1987) World Health Organization. Histological Typing of Cancer and Precancer of the Oral Mucosa. Berlin: Springer-Verlag

Pyke C, Salo S, Ralfkiaer E, Romer J, Dano K, Tryggvason K (1995) Laminin-5 is a marker of invading cancer cells in some human carcinomas and is coexpressed with the receptor for urokinase plasminogen activator in budding cancer cells in colon adenocarcinomas. Cancer Res 55: $4132-4139$

R Development Core Team (2007) R: a language and environment for statistical computing. R Foundation for Statistical Computing, Vienna, Austria. ISBN 3-900051-07-0, URL: http://www.R-project.org

Ramos DM, Chen BL, Boylen K, Stern M, Kramer RH, Sheppard D, Nishimura SL, Greenspan D, Zardi L, Pytela R (1997) Stromal fibroblasts influence oral squamous-cell carcinoma cell interactions with tenascin-C. Int J Cancer 72: $369-376$

Ruokolainen H, Päk̈kö P, Turpeenniemi-Hujanen T (2004) Expression of matrix metalloproteinase- 9 in head and neck squamous cell carcinoma: a potential marker for prognosis. Clin Cancer Res 10: 3110-3116 
Savinov AY, Remacle AG, Golubkov VS, Krajewska M, Kennedy S, Duffy MJ, Rozanov DV, Krajewski S, Strongin AY (2006) Matrix metalloproteinase 26 proteolysis of the NH2-terminal domain of the estrogen receptor beta correlates with the survival of breast cancer patients. Cancer Res 66: 2716-2724

Stadlmann S, Pollheimer J, Moser PL, Raggi A, Amberger A, Margreiter R, Offner FA, Mikuz G, Dirnhofer S, Moch H (2003) Cytokine-regulated expression of collagenase-2 (MMP-8) is involved in the progression of ovarian cancer. Eur J Cancer 39: 2499-2505

Steidler NE, Reade PC (1984) Experimental induction of oral squamous cell carcinomas in mice with 4-nitroquinolone-1-oxide. Oral Surg Oral Med Oral Pathol 57: $524-531$

Swango PA (1996) Cancers of the oral cavity and pharynx in the United States: an epidemiologic overview. J Public Health Dent 56: 309-318

Tamrazi A, Carlson KE, Daniels JR, Hurth KM, Katzenellenbogen JA (2002) Estrogen receptor dimerization: ligand binding regulates dimer affinity and dimer dissociation rate. Mol Endocrinol 16: 2706-2719

Teixeira G, Antonangelo L, Kowalski L, Saldiva P, Ferraz A, Silva FG (1996) Argyrophilic nucleolar organizer regions staining is useful in predicting recurrence-free interval in oral tongue and floor of mouth squamous cell carcinoma. Am J Surg 172: 684-688

Törnwall J, Carey AB, Fox RI, Fox HS (1999) Estrogen in autoimmunity: expression of estrogen receptors in thymic and autoimmune $\mathrm{T}$ cells. J Gend Specif Med 5: 33-40
Ulziibat S, Ejima K, Shibata Y, Hishikawa Y, Kitajima M, Fujishita A, Ishimaru T, Koji T (2006) Identification of estrogen receptor betapositive intraepithelial lymphocytes and their possible roles in normal and tubal pregnancy oviducts. Hum Reprod 9: 2281-2289

Väänänen A, Srinivas R, Parikka M, Palosaari H, Bartlett JD, Iwata K, Grenman R, Stenman UH, Sorsa T, Salo T (2001) Expression and regulation of MMP-20 in human tongue carcinoma cells. J Dent Res 80: $1884-1889$

Välimaa H, Savolainen S, Soukka T, Silvoniemi P, Mäkelä S, Kujari H, Gustafsson JA, Laine M (2004) Estrogen receptor-beta is the predominant estrogen receptor subtype in human oral epithelium and salivary glands. I Endocrinol 180: 55-62

Weidner N, Semple JP, Welch WR, Folkman J (1991) Tumor angiogenesis and metastasis - correlation in invasive breast carcinoma. $N$ Engl J Med 324: $1-8$

Weinreb PH, Simon KJ, Rayhorn P, Yang WJ, Leone DR, Dolinski BM, Pearse BR, Yokota Y, Kawakatsu H, Atakilit A, Sheppard D, Violette SM (2004) Function-blocking integrin alphavbeta6 monoclonal antibodies: distinct ligand-mimetic and nonligand-mimetic classes. J Biol Chem 279: $17875-17887$

Ylipalosaari M, Thomas GJ, Nyström M, Salhimi S, Marshall JF, Huotari V, Tervahartiala T, Sorsa T, Salo T (2005) Alpha v beta 6 integrin downregulates the MMP-13 expression in oral squamous cell carcinoma cells. Exp Cell Res 309: 273-283 